Please Cite Final Version; Critical Philosophy of Race 9, no. 2: 342-368.

\title{
Active Ignorance, Antiracism, and the Psychology of White Shame Eliana Peck
}

Active white ignorance is accompanied by an epistemic and affective insensitivity that allows American white people to avoid the negative affect that might typically accompany harmdoing.

Resisting active ignorance about racism and white supremacy, therefore, often gives rise to shame. Yet, thinkers have debated the value of shame for white people's antiracism. This article asserts that shame is an appropriate response for white people recognizing our culpability for and complicity in racist injustices and violence. However, the article exposes problems with philosophical accounts of white shame, and draws on recent psychological research to show that contextual factors actually determine whether shame can support white antiracism. The article proposes a role for shame in what José Medina calls an "ethics and epistemology of discomfort," arguing that there are conditions under which shame may encourage the sustained self-interrogation, sensitivity, and humility required if white people are to contribute meaningfully to antiracist action.

At the intersection of critical race theory, ethics, and social epistemology is literature on whiteness, and on the affective and epistemic traits that accompany American white people's investments in, and sometimes resistance to, white supremacy. This project brings together two topics within that literature: active white ignorance and white shame. Unlike a mere lack of knowledge, active white ignorance is a method of culpable not-knowing, accompanied by an insensitivity - epistemic and affective numbness to certain perspectives and experiences - that allows many white people to be complicit in and culpable for racist harms while maintaining the fiction that they are non-racist and morally good. ${ }^{1}$ Many white people will never attempt to resist active ignorance. However, if some white people are to contribute positively to antiracist political action, active ignorance will need to be reckoned with; white people will need to face our ongoing investments in white supremacist institutions and structures, as well as our moral responsibility for the racist violence about which we have been culpably insensitive. ${ }^{2}$ The difficulty of this task means that the process of reckoning with active white ignorance and insensitivity will often give rise to shame.

However, thinkers have debated the value of shame for white people's antiracism. Partly responding to widespread criticisms of "white guilt," philosophers including Samantha Vice, 
Please Cite Final Version; Critical Philosophy of Race 9, no. 2: 342-368.

Chris Lebron, Daniel Haggerty, and Alexis Shotwell have suggested that shame may be appropriate, even helpful, for white people newly working to resist active ignorance and participate in antiracist politics. But others - most notably Shannon Sullivan - have argued that shame is often destructive, leading to withdrawal and anger rather than transformation.

My view is that shame is an appropriate response for white people recognizing our culpability for and complicity in racist injustices and violence. However, I maintain that many philosophical accounts of white people's shame are flawed, misguidedly treating shame as a morally required response to whiteness itself or disavowing its significance altogether. Drawing on newer psychological research, I argue that whether or not shame can support critical selfreflection, transformation, and political action actually depends on contextual factors; however, shame may play a role in advancing white people's antiracist efforts. I propose a place for shame in what José Medina calls an "ethics and epistemology of discomfort," which scholars have argued is required of white people seeking to participate in sensitive - as opposed to insensitive antiracist politics. ${ }^{3}$ I argue that shame that arises appropriately as white people resist active ignorance regarding our complicity in racist structures, as well as our insensitivity regarding the infliction of specific harms, may encourage the sustained self-interrogation, sensitivity, and humility that is required. If this is the case, then white people should not disavow appropriate shame when we feel it, but aim to discover and create the conditions under which shame might play such a role.

I am aware of the risks of writing about white emotion in the context of antiracist politics, and of this article's extremely limited scope. My discussion begins at a stage of transformation that many white people will never even aim to achieve, and I do not provide an account of how people reach this point. ${ }^{4}$ Furthermore, there is a legitimate worry that projects like this one 
Please Cite Final Version; Critical Philosophy of Race 9, no. 2: 342-368.

harmfully re-center white people's experiences and emotions in allegedly antiracist discourse; white feminists in particular have often "reflected" on racism in ways that only secure white comfort. ${ }^{5}$ However, I also follow Linda Martín Alcoff and others in thinking that in addition to exposing white people's investments in white supremacy, "We need also to affirm that some of the time, in some respects even when not in all, whites empathize and identify with nonwhites, abhor how white supremacy has distorted their social interactions, and are willing to make significant sacrifices toward the eradication of white privilege." ${ }^{6}$ I suspect, further, that my audience will include many white academics who take themselves to be antiracist, and who, like me, have felt race-related shame. Finally, I agree with those who have insisted that white people self-problematize, and accept the burden of dealing with our epistemic and affective failures. As Ijeoma Oluo writes:

Your survival has never depended on your knowledge of white culture. In fact, it's required your ignorance ... People of color have been begging you to see what you are doing and why ... Find yourselves white people. Find yourselves so that you can know what whiteness is. Find yourselves so that you can determine what you want whiteness to be ... Find yourselves so that racism no longer surprises you. ${ }^{7}$

I therefore proceed in the hopes of remaining sensitive to the risks and limitations of this article, emphasizing the broader antiracist political work that is required of white people.

\section{Active White Ignorance and Insensitivity}

Active white ignorance is a form of ignorance that is consciously and unconsciously produced by and for white people, which obscures and excludes race-related knowledge from white people's attention. Cultivated within and maintained by norms, habits, discourses, social imaginaries, and institutions, active white ignorance is the result of what W.E.B. Du Bois called 
Please Cite Final Version; Critical Philosophy of Race 9, no. 2: 342-368.

a project of "emphasis and omission," and is therefore different from innocent gaps in understanding. ${ }^{8}$ In Alcoff's words, active white ignorance is a "substantive epistemic practice in itself," and the result of what Charles Mills characterizes as an agreement to "misinterpret the world." 9 The maintenance of active ignorance comes at the expense of people of color; as Paul Taylor explains, actively ignorant white people may circumscribe their networks of care and concern so that the experiences and perspectives of people of color fade from view. ${ }^{10}$ Thus, active white ignorance is both a systemic feature of a racially unjust social structure and an everyday habit that makes the perpetration of particular wrongs more likely.

José Medina argues that active white ignorance is accompanied by an epistemic and affective trait that he calls insensitivity. He writes, "Insensitivity involves being cognitively and affectively numbed to the lives of others: being inattentive to and unconcerned by their experiences, problems, and aspirations; and being unable to connect with them and to understand their speech and action." ${ }^{11}$ Insensitivity, Medina explains in a later text, operates "by projecting our own truths and meanings on others, by distorting the significance of their experiences ... [hiding] people's lives, erasing their voices and suppressing their concerns, interests, and aspirations." "12 Focusing on the affective component of racial insensitivity, he comments, "Racial insensitivity ... involves the inability to feel concerned and to have an entire array of emotions such as empathy, sympathy, compassion, and so on." ${ }^{\prime 13}$ Insensitivity therefore consists firstly in an epistemic and affective stance toward others, one that makes wrongdoing more likely and easier to ignore.

Importantly, however, insensitivity also impacts many white people's affective and epistemic orientations toward ourselves. Insensitivity allows white people to ignore the limits of our perspectives and the ways in which we acquire and maintain our race-related ignorance. ${ }^{14}$ 
Please Cite Final Version; Critical Philosophy of Race 9, no. 2: 342-368.

White people's insensitivity is therefore often experienced, and exhibited, as a kind of epistemic and affective comfort. Through insensitivity, white people can avoid feeling unease about our social and economic privilege, pain over the suffering of people of color, anxiety surrounding our complicity in that suffering, or pressure from a perceived responsibility to resist. ${ }^{15}$ An insensitive white person may preserve the self-conception that Sullivan refers to as the "good white person" or what Janine Jones calls "goodwill whites"; in Marilyn Frye's words, she may maintain "perfect confidence" that she "is not prejudiced, not a bigot, not spiteful ... [and] does not engage in favoritism or discrimination." $" 16$ Insensitivity allows white people to ignore uncomfortable facts about ourselves and to sidestep the negative emotions that might typically accompany a person's sense that they have benefited from injustice or caused harm.

Despite the pervasiveness of active white ignorance, thinkers including Alcoff (2015), Shotwell $(2011 ; 2017)$, and George Yancy $(2015 ; 2018)$ have noted that the last decade has been tumultuous for white subjectivity, and has led at least some white people to work toward selftransformation and antiracist political action. Furthermore, as Mills notes, if we correctly understand active ignorance and insensitivity as produced, then we should see that it can also be resisted. ${ }^{17}$ In the next section, I consider how self-work and antiracist action by white people requires that we acknowledge our participation in violence and resist the insensitivity that provides for our comfort. These efforts, I explain, will often give rise to shame.

\section{Shame and Resisting Active White Ignorance}

Confronting active ignorance can be immensely difficult for the "good" white person, because doing so requires that one problematize areas of one's life that one has learned to treat as unproblematic, even irrelevant. James Baldwin explains the discomfort that accompanies such challenges to white people's racial self-conceptions: 
Please Cite Final Version; Critical Philosophy of Race 9, no. 2: 342-368.

Try to imagine how you would feel if you woke up one morning to find the sun shivering and all the stars aflame. You would be frightened because it is out of the order of nature. Any upheaval in the universe is terrifying because it so profoundly attacks one's sense of one's own reality. Well, the black man has functioned in the white man's world as a fixed star, as an immovable pillar, and as he moves out of his place, heaven and earth are shaken to their foundations. ${ }^{18}$

Facing one's active ignorance and insensitivity requires, in Yancy's terms, that one become "un-sutured" from narratives about oneself and the world. ${ }^{19}$ It requires that white people become vulnerable to the evidence that we benefit from wrongs and injustices which we did not choose but from which we benefit, and that our privilege and comfort comes at the expense of others' suffering. Therefore, white people genuinely working to resist active ignorance are likely to feel considerable emotional stress and pain.

However, thinkers have pointed out that white people's emotional expressions concerning racism - sometimes denoted by "white guilt" or "white fragility" - are often flawed. ${ }^{20}$ White people's negative feelings about racism are often deployed strategically to reassure us of our moral goodness, or as a defense mechanism that signals weakness and justifies withdrawal; self-transformation and political action rarely follows. Although most believe that white people have much to feel negatively about, what is being criticized, explains Yancy, is "the temptation for uncritical confessional expurgation, guilt, and shame ... [which] can easily function as forms of seeking shelter from doing something about the ongoing reality of white racism." 21

Partly in response to widespread criticisms of "white guilt," some philosophers have asked whether shame might be a more appropriate, and perhaps more useful, response. While 
Please Cite Final Version; Critical Philosophy of Race 9, no. 2: 342-368.

guilt is characterized by one's perception that specific actions or omissions were wrongful, shame reflects a negative evaluation of the self - of "who one is" - often based on a perceived failure with regard to a moral commitment or in the eyes of (real or imagined) others. ${ }^{22}$ Shame, perhaps, more accurately captures white people's negative feelings about how being born white in this racial context makes us the beneficiaries of a harmful system for which we might not be culpable, but - because of social and economic privilege, and the epistemic and ethical comfort that accompanies active ignorance - in which we are complicit. ${ }^{23}$ Shotwell explains: "For a lot of us white people, there's an urge to reject any connection to [our history], a wish to just not feel bad or responsible. White shame is realizing that we are implicated in and benefit from the harm being done to other people, right now . . . It doesn't matter if we . . . say we don't like it; we still benefit from racism at every scale and in every way." ${ }^{24}$ Furthermore, guilt and shame are thought to have different moral and social functions; guilt may motivate apology, but shame is what, in the words of Bernard Williams, encourages one to "rebuild the self that has done these things and the world in which that self has to live." ${ }^{25}$ Perhaps, some think, shame might be more useful for efforts, not just to fix particular harms, but to resist the far-reaching effects of racism and white supremacy.

I agree that shame - more so than guilt - is an appropriate reaction for white people in the contemporary United States. While white people who have committed specific wrongful acts might also be justified in feeling guilt, shame more adequately captures the bad feeling of facing our uncritical enjoyment of racist systems and institutions, including those that we did not choose but from which we continue to benefit. Shame is an appropriate thing for us to feel in response to those injustices that - although sustained by the acts of individuals - are structural, systemic, and give rise to shared responsibility. ${ }^{26}$ Importantly, what makes shame so 
Please Cite Final Version; Critical Philosophy of Race 9, no. 2: 342-368.

appropriate is that the inherited privileges and benefits of whiteness come at the expense of ongoing harmdoing; in other words, shame is a warranted response not just to white social and economic privilege but to the accurate recognition that this privilege persists in a tradeoff with violence, and thus constitutes a kind of complicity.

Although my primary interest is in the warranted shame that may arise as white people resist active ignorance about structural injustice, there is something else that makes shame appropriate in this context. Active ignorance and insensitivity are learned habits that, in addition to having structural components, make individual white people more likely to inflict (and deny responsibility for) microagressions and other wrongs on a daily basis. In addition to coming to terms with the complicity entailed by white privilege, recognizing that the epistemic and affective habits of whiteness have with overwhelming likelihood led persons to commit particular wrongs may also give rise to warranted shame. More so than guilt - which tends to arise with respect to wrongs conceptualized as discrete, individually-perpetrated violations shame adequately captures the relationship between instances of microagressive or harmful behavior, active white ignorance, and structural injustice. For this reason, although I see shame most centrally as an appropriate response to white people's complicity in structural injustice, shame is also warranted as individuals reckon with the ways that active ignorance and insensitivity have contributed to our having inflicted violence - sometimes unwittingly but often culpably - in our daily lives.

However, my view is that much of the literature on white shame suffers from problems, treating shame as either too essential to white identity or mistakenly overlooking its value. In the next section, I analyze some existing accounts of white shame.

\section{Philosophers on White Shame}


Please Cite Final Version; Critical Philosophy of Race 9, no. 2: 342-368.

Philosophical accounts of shame vary widely, but in the last fifteen years, a number of accounts have emerged that treat shame as a primary emotion through which people who are implicated in wrongdoing should approach their moral situations. Michael Morgan argues that shame is a moral response to the recognition that one lives in a world marred by atrocities and suffering, including those related to racism. ${ }^{27}$ Shame, he suggests, should be deliberately and indefinitely cultivated by those of us complacent in the face of such horrors, to remind us of our "moral inadequacy.",28

Daniel Haggerty more specifically details the "grounds for feeling shame for being white in America," including white privilege, complicity in racist oppression, and the general fact of being "identified with whiteness." 29 According to Haggerty, shame is what white people should feel in response to the "moral taint" that our relationship to racism entails. ${ }^{30}$ Although he notes that white people needn't be ashamed of "all whiteness" - some white people, he explains, have resisted white supremacy - Haggerty insists that shame about "being white" could serve as a launchpad for antiracism. ${ }^{31}$ Haggerty argues that shame is valuable because it motivates white people "to work for forgiveness and reconciliation" and can give rise to "justified anger" that drives resistance. ${ }^{32}$

In the controversial "How Do I Live in This Strange Place?" (2010) and elsewhere, Samantha Vice argues for the value of white people's shame in post-apartheid South Africa. Vice maintains that in the face of white privilege, indifference, and whiteness itself, feeling shame is "moral emotional duty" for white people. ${ }^{33}$ In a recent article, she stresses the "bad luck" of being white, of being born into a racist history that is "not under [one's] control" and in which one's character will be shaped by racist conditions that one did not create; her phrasing neglects white people's responsibility for harmdoing and ongoing investments in white 
Please Cite Final Version; Critical Philosophy of Race 9, no. 2: 342-368.

supremacy. ${ }^{34}$ Vice recommends that white people respond to shame with "private project[s] of self-improvement," and make ourselves "invisible and unheard" in the public sphere. ${ }^{35}$ More recently, she adds that "taking responsibility" through shame and self-work "can be the start of an apology to those others for our position of privilege over them, chosen or not."36

While each of these figures approach shame differently, each is situated in a growing cohort of philosophers who have discussed shame as a morally required response - something that people ought to feel, and ought to cultivate if they do not feel it - for white people reflecting on racial injustice. But although I agree that shame is an appropriate response to our complicity in racist structures, I am concerned about Haggerty's and Vice's view that white people ought to indefinitely direct their shame toward whiteness and the "bad luck" of being born white. These suggestions imply, I think misguidedly, that whiteness is the moral crime to which antiracism should primarily respond. This emphasis is problematic, first, because it has the effect of essentializing whiteness as bad, or at least, treating the badness of whiteness as fixed. This unnecessary move makes it harder to identify that habits like active ignorance are learned, contingent, and should be resisted.

Second, and more seriously, my worry is that to recommend that shame be directed toward whiteness distracts from the very real ways in which the inherited social and economic benefits of white supremacy - and the habits, like active ignorance and insensitivity, encouraged by this system - morally implicate white people in wrongdoing. While judgments of culpability and blame may be inappropriate, the nature of structural injustice is that to benefit $i s$ to be complicit and responsible (at least) in a forward-looking sense. ${ }^{37}$ Often, this complicity and responsibility is mistaken as blameworthiness and culpability and, defensively, rejected. But complicity is the other side of white privilege. It is complicity that makes white people's shame 
Please Cite Final Version; Critical Philosophy of Race 9, no. 2: 342-368.

so appropriate, not merely the fact that we were born white. My concern is that the approach recommended by Haggerty and Vice - to direct shame toward whiteness - risks obscuring white people's complicity and its significance. ${ }^{38}$

A final point of issue is that neither Vice nor Haggerty includes empirical support for their claims that feeling shame over whiteness will motivate transformation, nor is it clear that the effects they describe - retreating from the public sphere, feeling justified anger, apologizing (or understanding shame itself as "the start of an apology"), working for forgiveness - are even desirable, and not simply worrisome. It seems to me that these responses harmfully re-center white people's emotions and experiences, and do not support the kind of political transformation and action that antiracism actually requires. My concerns about these thinkers' suggestions lead me to Shannon Sullivan's criticisms of the view that shame should figure centrally in white antiracism.

Citing figures including Michael Morgan and Alexis Shotwell, Sullivan criticizes the way that shame "has emerged as the recommended emotion for white people today who care about racial justice." ${ }^{39}$ She explains that fear, guilt, and shame have often fueled racist violence; even when these emotions have been integrated into attempts at repair, these responses are frequently little more than "brief gestures," which serve white people's notions of ourselves as "good people" but fail to motivate sustained activism. ${ }^{40}$ In fact, Sullivan writes, "I'm concerned that more often than not, shame tends to deflate a person, to rob her of the vitality and energy it will take to make a sustained kind of change in herself or the world. The experience of a shrunken self doesn't motivate beneficial action. It kills it." ${ }^{41}$ Sullivan warns specifically against views that propose that one's racial identity be ruled by negative affect; defining oneself by shame, she thinks, provokes defensiveness, paralysis, self-hatred, and anger toward more vulnerable 
Please Cite Final Version; Critical Philosophy of Race 9, no. 2: 342-368.

others. ${ }^{42}$ Sullivan therefore argues that shame is not valuable for white antiracism. Insisting that sustained action must be motivated by more "affirming" emotions, Sullivan suggests that white people instead cultivate a form of "unburdened" self-love. ${ }^{43}$

Sullivan is right to be concerned about shame. It is true that white people's expressions of race-related affect often have defensive, debilitating, or harmful effects; furthermore, I agree that defensiveness and anger are more likely if shame is deliberately cultivated or treated as central to how white people ought to view ourselves going forward. This is a further concern that I have with accounts like Morgan's, Vice's, and Haggerty's; shame that is indefinitely directed toward whiteness is, I think, more likely than not to encourage defensiveness. ${ }^{44}$

However, I am not persuaded that shame must have the negative effects against which Sullivan warns, nor by her conclusion that shame should be avoided in favor of a more positively-valanced affect. Sullivan supports her conclusions with dated psychological research by Helen Block Lewis and June Price Tangney; as I discuss in the next section, this work is known for its negative assessment of shame. ${ }^{45}$ But in the last decade or so, newer psychological research has challenged this model; studies have shown that shame is more often associated with repair and transformation than had been previously thought. This literature indicates that there may be conditions under which white people's shame could be integrated into, and even aid, efforts to resist active ignorance and engage in antiracist political action.

If there are conditions under which shame could play such a role, my view is that we ought to reject Sullivan's argument that white people's shame should be renounced in favor of self-love. Because insensitivity allows many white people to avoid negative affect concerning our complicity in and culpability for racist harms, resisting active ignorance and insensitivity will often give rise to shame, and that shame is warranted. Under such circumstances, positive affects 
Please Cite Final Version; Critical Philosophy of Race 9, no. 2: 342-368.

do not so easily replace the negative; furthermore, my sense is that to not experience shame when shame is so appropriate may indicate a lack of appreciation of our responsibility, making good antiracist responses unlikely. I follow Sara Ahmed in thinking that although the value of shame has its limits, "the process of being moved by the past seems better than the process of remaining detached from the past, or assuming that the past has "nothing to do with us.",46 Although white people newly resisting active ignorance are often culpable for not having done so earlier, we now need to reckon with the shame that appropriately accompanies becoming sensitive to those harms we have ignored.

In the next section, I discuss the evidence that whether or not shame is associated with positive outcomes depends on a number of circumstantial features. I argue that if, as the evidence suggests, there is a good chance that the shame appropriately felt by white people may support antiracist change and action, then we - white people - should consider how to quickly identify and create the conditions likely to support that response.

\section{Psychological Insights Regarding Shame}

Dominant scholarly conceptions of shame have been shaped by the early psychological research of Helen Block Lewis, June Price Tangney, and colleagues, who define shame as an emotion that self-consciously responds to perceived failures of the self. ${ }^{47}$ Drawing on empirical studies, these researchers provide a picture of shame as acutely painful and characterized by feelings of worthlessness, powerlessness, exposure, and that one's very self has been "split" or "impaired." ${ }^{48}$ Shame has also been empirically associated with denial, withdrawal, paralysis, and other-directed aggression. ${ }^{49}$ While guilt is taken to be capable of motivating prosocial desires to "confess, apologize, or repair," shame is seen as comparatively maladaptive, leading individuals to "hide, escape, or strike back." ${ }^{50}$ These accounts have contributed to a widespread 
Please Cite Final Version; Critical Philosophy of Race 9, no. 2: 342-368.

conception of shame as an essentially debilitating emotion.

However, in the last decade or so, some psychologists have drawn attention to inconsistencies in the dominant view of shame. ${ }^{51}$ What these researchers point out is that, although there is certainly data that supports the negative picture, there is also a great deal of contradictory data, and this has been underappreciated by psychologists whose work relies on the conception of shame traceable to early texts by Lewis and Tangney. In fact, shame has been associated with transformation and repair in a variety of cases; these results pose a problem for the dominant view of shame as essentially maladaptive.

Why are the empirical results on shame so mixed? Researchers think that past failures to distinguish shame from other emotions may have tainted the data. Jesse Allpress and colleagues argue that existing results on shame confuse or conflate "image shame" - the feeling that may accompany "looking bad" in front of others - and "moral shame," the feeling that one has failed morally. ${ }^{52}$ In several studies of hundreds of British students' shame over the abusive treatment of Iraqis by British soldiers, they report, "The data are quite clear that, once their shared variance is partialed out, shame arising from a threatened social image is associated with negative outcomes [avoidance, cover-up, anger, and victim blame], whereas shame arising from a threatened moral standing is associated with positive outcomes [support for apology, reparations, and compensation to victims]."

Nicolay Gausel, Colin Wayne Leach, Vivian L. Vignoles, and Rupert Brown also criticize how shame has been studied in the past. They attribute the dominant, negative view of shame to a failure to differentiate between shame - a self-reflective, affective, negative appraisal - and feelings of rejection, inferiority, and condemnation. ${ }^{54}$ In two studies, Gausel et al. isolate these responses and survey hundreds of Norwegians regarding Norway's 
Please Cite Final Version; Critical Philosophy of Race 9, no. 2: 342-368.

discriminatory and violent treatment of the Tater ethnic minority in the twentieth century. ${ }^{55}$ Results show that "unlike felt rejection and inferiority, felt shame was uniquely tied to the appraisal that the in-group suffered a moral defect" and predicted remorse and desires to make restitution; shame was also associated with less defensiveness than it has been in studies where these emotions were not distinguished from each other. ${ }^{56}$

Other studies indicate that whether or not shame will be associated with positive responses - which may include personal transformation, attempts at reparation, and political engagement - depends on the context in which shame is felt, expressed, and received by others. Buch, Gausel, and De Hooge, Zeelenberg, and Breugelmans independently observe that shame is less likely to lead to withdrawal if the person feeling shame is able to identify opportunities for self-work and reparative action, particularly in communion with others. ${ }^{57} \mathrm{We}$ may find an example of this result in a study of 125 white Australians' shame regarding the treatment of Indigenous peoples. Participants were given the opportunity to sign "what they believed to be a real petition to be sent to their member of parliament, indicating their support for the upcoming apology" from the Australian government to indigenous people. ${ }^{58}$ Allpress et al. found that "the odds of signing the petition were 1.44 times higher for each one-point increase in reported shame." 59 Of course, signing a petition is a relatively low-stakes, low-effort form of political engagement. Still, the fact that shame predicted petition-signing in this case is promising; this result also supports the aforementioned view that identifiable opportunities for directing shame into reparative or political action may promote engagement rather than withdrawal.

Some studies indicate that shame that is met by others with empathy, toleration, and mutual vulnerability - as opposed to rejection or humiliation - is associated with positive responses. In a 2012 study of people struggling with addiction, participants were encouraged to 
Please Cite Final Version; Critical Philosophy of Race 9, no. 2: 342-368.

discuss their shame with each other in group therapy. ${ }^{60}$ Compared to a control group, participants felt more shame initially but experienced a larger reduction in shame after four months; participants also were more likely to have continued to seek out support and treatment. Luoma et al. theorize that the opportunity for participants to experience shame "openly and mindfully" contributed to better functioning, reintegration into healthy social networks, and diminishing shame over time. ${ }^{61}$ In several other contexts, shame met with empathy and support has been associated with increased self-awareness, humility, and resilience. ${ }^{62}$

A final, promising result comes, surprisingly, from June Price Tangney. Countering Tangney's accounts from the 1980s and 1990s, and citing articles by Gausel and De Hooge, Tangney, Stuewig, and Martinez have recently argued that there are "two faces of shame," one with "constructive potential." 63 Their longitudinal study of 476 people who had been in jail showed that if subjects "took personal responsibility" rather than "externalized blame," shame was correlated with reduced recidivism. ${ }^{64}$ Tangney, Stuewig, and Martinez conclude that although for decades many have "emphasized the dark, destructive side of shame," in fact, "shame has both a defensive pathway . . . and a potentially prosocial pathway." 65

None of the studies that I have discussed in this section predict how a particular white person, or group of white people, will experience shame. ${ }^{66}$ However, what I find significant about these studies is that they reveal a problem with the philosophical views - which include Morgan's, Haggerty's, Vice's, and Sullivan's - that take shame to be primarily good or bad for white antiracism. In fact, what emerges from the empirical literature is that shame is sometimes associated with reparative, forward-looking responses, and more often than older research might lead us to expect. In light of these results, and given my view that shame is an appropriate thing for us to feel, white people should ask whether there are conditions under 
Please Cite Final Version; Critical Philosophy of Race 9, no. 2: 342-368.

which shame could play a positive role in our antiracist projects. The studies that I have reviewed in this section, I think, suggest that there are conditions under which appropriate shame might play such a role, although it will take time and effort for white people to determine and create these conditions.

However, our efforts may proceed even as we acquire more data. Applying the existing research, we may ask: how often is shame expressed in white communities, and what is our response to it? Are we treating shame as itself shameful, or encouraging those who express shame to be resilient, and to move forward with self-critique, transformation, and resistance? Can we encourage other white people to see shame as a call to responsibility - rather than a sign of bad image or inferiority - and help them brainstorm moral responses? Are there ways to validate the legitimacy of our shame, without treating shame as sufficient for moral goodness? Are we treating shame as one step in a broader process of respectfully following the leadership of people of color in antiracist political action? How are we educating each other about the political work that is required? Reflecting on these questions, reconceptualizing our methods, and improving our practices is, I think, a more promising task (among others) for philosophers than that of determining whether shame is, as a rule, good or bad for white antiracism.

To be clear - and although the ways that people of color have encouraged white antiracism should not be underappreciated - engaging in the work for which I have called is a task for white people. Shame is not an excuse for white people to ask people of color to "care for us" - a too-common demand, already - or to further prioritize white feelings. Only rarely are white people even justified in expressing racial shame to people of color; this is often driven by a desire for absolution, and is a harmful display of active ignorance. The task at hand is for white people to identify how to meet shame in ourselves and each other, in a manner that 
Please Cite Final Version; Critical Philosophy of Race 9, no. 2: 342-368.

usefully and quickly facilitates our participation in wide-reaching, antiracist action.

I have focused, in this section, on the possibility of incorporating shame into white people's antiracist efforts. However, in the final section of the article, I shift my focus slightly in order to attend to an ambiguity that arises from my criticisms of the philosophical literature on shame. As noted, I share Sullivan's worries about accounts of shame that treat shame as central to whiteness or white identity going forward; these accounts may well encourage "image shame," and thus, defensiveness and withdrawal. However, there may be an alternative role for shame in white people's antiracist projects. In this final section, I return to the literature on active ignorance and propose a role for shame in the epistemic and affective discomfort that some have argued is required of white people resisting active ignorance and insensitivity.

\section{A Role for Shame in White Antiracism}

While insensitivity allows many white people complicit in racism to maintain a comfortable idea of themselves as blameless, the shame that may appropriately arise alongside efforts to resist active ignorance is, in Shotwell's words, "a paradigmatic example of discomfort." ${ }^{\prime 67}$ This characterization usefully corresponds to what others have agreed is needed if white people are to contribute to antiracist sociopolitical action. José Medina insists that what is required of white people is a lasting, critical stance that he calls an "ethics and epistemology of discomfort." In contrast to that of insensitivity, this stance involves making peace with the fact that antiracism requires sustained self-interrogation and effort, and often produces a great deal of ambiguity regarding how one should feel about oneself. ${ }^{68}$ Scholars of education, too, have developed "pedagogies of discomfort" as a tool for encouraging self-reflection and vulnerability in their students when discussing race; they argue that making space for participants to sit with and interrogate their stress and anxiety, particularly when exchanges get 
Please Cite Final Version; Critical Philosophy of Race 9, no. 2: 342-368.

heated, is key for forestalling defensiveness, anger, and withdrawal. ${ }^{69}$

The existing literature on shame points to how it might support the self-reflective, critical stance that is needed of white people. Shame responds to perceived failures of the self and feelings of deficiency with respect to moral standards. ${ }^{70}$ Although these characteristics carry no guarantees, the self-reflexive nature of shame might encourage the kind of critical reflection for which thinkers like Medina and Shotwell have called. Reckoning with our complicity for ongoing injustice and culpability for specific harms - as well as the greater likelihood of doing harm that active ignorance and insensitivity entail - will be deeply discomfiting; however, the warranted shame that accompanies this reckoning may be an important stage of taking seriously how the inheritances of white supremacy and learned habits of whiteness give rise to forward-looking responsibilities. ${ }^{71}$

Furthermore, as Lisa Guenther explains, shame is an emotion that makes one feel exposed to the gaze of others, and upsets one's relation to the world as a privileged subject. ${ }^{72}$ Many have rightly argued that white people with antiracist commitments must reject the uncritical comfort for which insensitivity provides, and become more attentive and responsive to the perspectives, experiences, and judgments of people of color. Under the right conditions, perhaps the features of shame highlighted by Guenther might encourage critical self-reflection and sensitivity - as opposed to insensitivity - to persons and perspectives not treated as relevant before.

We may not always know how to deal with our shame. But as Medina, Shotwell, and Boler show, hesitancy and uncertainty are actually valuable if white people are to contribute meaningfully to antiracist politics. As Shotwell explains, "Shame can provide a gap in practice; it can stop the conceptual habits we comfortably use to navigate the world...I see some use, 
Please Cite Final Version; Critical Philosophy of Race 9, no. 2: 342-368.

then, in shame's potential capacity to hold open, to not freeze, affective space." ${ }^{, 73}$ When shame arises, white people might encourage each other not to react defensively; instead, we may ask what precipitated our shame, and treat it as a prompt to reassess. We might follow the model displayed by Adrienne Rich and Audre Lorde, when Rich experiences anxiety over Lorde's remarks on race; Rich comments, "I may have to take a long hard look and say, 'Is this something I can use? What do I do with this?' . . 'How do I use this? What do I do about it?'” Lorde adds: "How much of this truth can I bear to see/and still live/unblinded?/ How much of this pain/can I use?"74 By listening to and interrogating shame, we might foster resilience rather than withdrawal; we might, as Ahmed writes, learn "to deal with such blockages, and [find] ways to get through.",75

Shame need not be the only affective stance by which white people relate to themselves or to others; indeed, this might lead to defensiveness and withdrawal. But one can experience shame about one's participation in wrongdoing without losing sight of other feelings, including eagerness about politics, love for others, pride at one's accomplishments, and hope for the future. ${ }^{76}$ Shame, as one feeling among many, might encourage white people to engage in antiracist politics with more humility, remaining alert to the ways in which we may go wrong and responding honorably if we do. I therefore envision a role for shame like that detailed by Berenice Fisher in "Guilt and Shame in the Women's Movement" (1984). She writes:

Even the most generous evaluation of our practice requires us to grant that we sometimes have failed. In this respect, we can expect our feelings of shame to remain with us, not as a mark of our inadequacy but as a sign of our commitment to act, as a mark of the tension between the present and the future, as a touchstone for understanding what we expect to achieve and how. Shame bids us to ask: do our goals 
Please Cite Final Version; Critical Philosophy of Race 9, no. 2: 342-368.

need reevaluating? How could we really fulfill them? Can we forgive ourselves for having failed, and try again ${ }^{77}$

Even if largely successful, white people engaging in antiracist political work will fumble, and shame will creep in. What Fisher points out, however, is that we can understand that shame as part of our transformation, rather than a sign of having failed. When we err, shame can signal where we have gone wrong and remind us to move forward with humility and sensitivity.

I therefore argue that there is a limited, but positive, place for shame in white people's resistance. The appropriateness of shame as a response to our active ignorance, insensitivity, and complicity means that we - white people, and white philosophers - should consider whether there are conditions under which shame might contribute to our antiracist efforts. If I am right that such conditions can be created, then while we may not have a moral responsibility to actively cultivate shame when we do not feel it, perhaps we ought not to disavow it for the sake of something like self-love. Instead, we may let ourselves feel shame while acknowledging and resisting our remaining investments in white supremacy, and make clear to ourselves and each other that shame without action is not enough. Perhaps we may learn to treat shame as one feature of a broader project of engaging in sensitive antiracist work. 
Please Cite Final Version; Critical Philosophy of Race 9, no. 2: 342-368.

1. José Medina, The Epistemology of Resistance: Gender and Racial Oppression, Epistemic Injustice, and Resistant Imaginations (New York: Oxford University Press, 2013b), xi, 17-8, 267; José Medina, “On Refusing to Believe: Insensitivity and Self-Ignorance” in Rationality Reconsidered: Ortega y Gasset and Wittgenstein on Knowledge, Belief, and Practice, ed. Astrid Wagner and José María Ariso (Chicago: De Gruyter, 2016), 191-5.

2. By "antiracist," I primarily refer to socio-political efforts to change or abolish racist behaviors, rules, institutions, and structures; white people's self-transformations are not inherently antiracist, but may be if they encourage behavioral change and socio-political resistance. 3. Medina, 2016, 188 and 193-8.

4. I do not discuss practices of shaming in this article. Although I do think that white people should encourage antiracism in each other, it is not clear that shaming is likely to produce responses other than defensiveness and withdrawal; evidence concerning the value of shame is not itself evidence in favor of shaming.

5. Sarita Srivastava, “'You're Calling Me a Racist?' The Moral and Emotional Regulation of Antiracism and Feminism," Signs 31, no. 1 (2005): 33-6; Sarita Srivastava, 2006, "Tears, Fears and Careers: Anti-racism and Emotion in Social Movement Organizations," The Canadian Journal of Sociology 31, no. 1 (2006): 68-9; Ijeoma Oluo, “White People: I Don’t Want You To Understand Me Better, I Want You To Understand Yourselves,” Medium: The Establishment, February 7, 2017, https://medium.com/the-establishment/white-people-i-dont-want-you-tounderstand-me-better-i-want-you-to-understand-yourselves-a6fbedd42ddf.

6. Linda Martín Alcoff, “What Should White People Do?”, Hypatia 13, no. 3 (1998): 7. 7. Oluo, 2017. 
Please Cite Final Version; Critical Philosophy of Race 9, no. 2: 342-368.

8. W.E.B. Du Bois, "The Souls of White Folk," in Black on White: Black Writers on What it Means to be White, ed. David R. Roediger (New York: Schocken Books, 1998 [1920]), 185-6 and 193.

9. Linda Martín Alcoff, "Epistemologies of Ignorance: Three Types," in Race and Epistemologies of Ignorance, ed. Shannon Sullivan and Nancy Tuana (Albany: State University of New York Press, 2007), 39; Charles W. Mills, The Racial Contract (Ithaca: Cornell University Press, 1997), 18.

10. Paul Taylor, "Race Problems, Unknown Publics, Paralysis, and Faith," in Race and Epistemologies of Ignorance, ed. Shannon Sullivan and Nancy Tuana (Albany: State University of New York Press, 2007), 136-7; see also Paul Taylor, “Silence and Sympathy: Dewey’s Whiteness," in What White Looks Like: African-American Philosophers on the Whiteness Question, ed. George Yancy (New York: Routledge, 2004), 230.

11. Medina, 2013b, xi.

12. Medina, 2016, 193.

13. Medina, 2013b, 210.

14. Medina, 2013b, 24 and 75-6; 2016, 191-5. In earlier texts, Medina refers to this as "metablindness" or "meta-insensitivity" (José Medina, "Color Blindness, Meta-Ignorance, and the Racial Imagination," Critical Philosophy of Race Special Issue: Beyond the Black/White Binary 1, no. 1 [2013a]; Medina, 2013b). More recently, however, he treats “insensitivity" as sufficiently encompassing (2016).

15. Medina, 2016, 187-8.

16. Shannon Sullivan, Good White People: The Problem with Middle-Class White Anti-Racism (Albany: State University of New York Press, 2014); Janine Jones, “The Impairment of Empathy 
Please Cite Final Version; Critical Philosophy of Race 9, no. 2: 342-368.

in Goodwill Whites for African Americans," in What White Looks Like: African-American

Philosophers on the Whiteness Question, ed. George Yancy (New York: Routledge, 2004), 68-

71; Marilyn Frye, "White Woman Feminist," in Willful Virgin: Essays in Feminism, 1976-1992

(Freedom, CA: Crossing Press, 1992), 154.

17. Charles Mills, "White Ignorance," in Race and Epistemologies of Ignorance, ed. Shannon

Sullivan and Nancy Tuana (Albany: State University of New York Press, 2007), 23.

18. James Baldwin, “A Letter to My Nephew,” The Progressive (1962).

19. George Yancy, "Introduction," in White Self-Criticality Beyond Anti-Racism: How Does It Feel to be a White Problem?, ed. George Yancy (New York: Lexington Books, 2015), xiv-xvi and xxiv-xxv.

20. See James Baldwin, "White Man's Guilt,” in Black on White: Black Writers on What it Means to be White, ed. David R. Roediger (New York: Schocken Books, 1998 [1965]), 320-3; Audre Lorde, Sister Outsider: Essays and Speeches (New York: Ten Speed Press, 1984/2007), 124; Sara Ahmed, “The Non-Performativity of Anti-racism,” Borderlands 5, no. 3 (2005); Srivastava 2005; Srivastava 2006; Mamta Motwani Accapadi, "When White Women Cry: How White Women's Tears Oppress People of Color," College Student Affairs Journal 26, no. 2 (2007); Shannon Sullivan, “On the Need for a New Ethos of White Antiracism," philoSOPHIA 2, no. 1 (2012): 25; Cherríe Moraga and Gloria Anzaldúa, “And When You Leave, Take Your Pictures With You: Racism in the Women's Movement," in This Bridge Called My Back: Writings by Radical Women of Color, $4^{\text {th }}$ ed., ed. Cherríe Moranga and Gloria Anzaldúa (Albany: State University of New York Press, 2015): 27 and 58; Yancy 2015; Oluo 2017; Luvvie Ajayi, “About the Weary Weaponizing of White Women's Tears.” Awesomely Luvvie (blog), 7 April, 2018, https://www.awesomelyluvvie.com/2018/04/weaponizing-white-women-tears.html; 
Please Cite Final Version; Critical Philosophy of Race 9, no. 2: 342-368.

Ruby Hamad, "How white women use strategic tears to silence women of colour," The

Guardian, 7 May 2018, https://www.theguardian.com/commentisfree/2018/may/08/how-whitewomen-use-strategic-tears-to-avoid-accountability; Robert Kuttner, "Stop Wallowing in Your White Guilt and Start Doing Something for Racial Justice," The American Prospect, 21 August, 2018, http://prospect.org/article/stop-wallowing-your-white-guilt-and-start-doing-somethingracial-justice.

21. Yancy, 2015, xiii.

22. Bernard Williams, Shame and Necessity (Berkeley: University of California Press, 1993), 8494; Christopher Lebron, The Color of Our Shame: Race and Justice in Our Time (New York: Oxford University Press, 2013), 18; Sara Ahmed, The Cultural Politics of Emotion, $2^{\text {nd }}$ ed. (Edinburgh: Edinburgh University Press, 2014), 105-8.

23. I take complicity to entail some manner of moral responsibility for harmdoing. I do not take a position, here, on whether white people's complicity is generally culpable; I follow Claudia Card in thinking that complicity in collectively-perpetrated wrongs need not entail culpability. She writes, "Participants in a faulty institution, and non-participants who are complicit, need not be culpable, although often they are. The nature and degree of their culpability varies with their individual positions and powers, options available to them, what they know or should know, and so on." Claudia Card, Confronting Evils: Terrorism, Torture, Genocide (New York: Cambridge University Press, 2010), 63.

24. Alexis Shotwell, "Is It White Shame?” Alexis Shotwell (blog), August 13, 2017, https://alexisshotwell.com/2017/08/13/white-shame/.

25. Williams, 1993, 94. 
Please Cite Final Version; Critical Philosophy of Race 9, no. 2: 342-368.

26. I emphasize the acts of individuals, not because I am opposed to theories of group agency, but simply in order to leave open the possibility of discussing individuals' varying degrees of participation in and responsibility for racist institutions.

27. Michael L. Morgan, On Shame (New York: Routledge, 2008), 22, 35, and 57.

28. Ibid., 34, 57-8 and 88-92.

29. Daniel Haggerty, "White Shame: Responsibility and Moral Emotions," Philosophy Today 53, no. 3 (2009): 312 and 316 [footnote 37]).

30. Ibid., 305.

31. Ibid., 312-4.

32. Ibid., 304.

33. Samantha Vice, “'How Do I Live in This Strange Place?”' Journal of Social Philosophy 41, no. 3 (2010): 329. Vice insists elsewhere that her goal is not to "essentialize" white people, but that her focus is instead on "whiteliness" (Samantha Vice, "Essentializing Rhetoric and Work on the Self," Philosophical Papers 45, nos. 1 and 2 (2016): 118-9 and 123). However, I find this claim hard to reconcile with the person-focused language in her 2010 and 2017 texts.

34. Samantha Vice, "Race, Luck, and the Moral Emotions," in The Routledge Companion to Philosophy of Race, ed. Paul C. Taylor, Linda Martín Alcoff, and Luvell Anderson (New York: Routledge, 2017), 447-8 and 451-5.

35. Vice, 2010, 335.

36. Vice, $2017,459$.

37. Iris Marion Young, Responsibility for Justice (New York: Oxford University Press, 2011), $108-9$. 
Please Cite Final Version; Critical Philosophy of Race 9, no. 2: 342-368.

38. There is a sense in which I agree with Vice and Haggerty that whiteness warrants shame, because on my view, whiteness entails privilege, which entails complicity, which warrants shame. However, I maintain that there is an important distinction between their accounts - which recommend directing shame toward whiteness - and my view that shame is an appropriate response to white people's complicity. My view is that Vice and Haggerty emphasize the wrong feature; to recommend shame as a response to whiteness - without stressing the relationship between whiteness and complicity - is both conceptually and politically problematic (for the reasons discussed in this section). I therefore maintain that there is a significant difference between my view and the approach recommended by Vice and Haggerty. I am grateful to my anonymous reviewer for pushing me to think more about this section.

39. Sullivan, 2014, 128.

40. Sullivan, 2012, 24-5; 2014, 134-5.

41. Sullivan, 2014, 134-5.

42. Sullivan, 2012, 26; 2014, 19.

43. Sullivan, 2012, 22-6 and 30-2; 2014, 134-5 and 145-7.

44. The research on "image shame" - discussed later in this article - provides a possible explanation for why this might be.

45. Sullivan, 2014, 135-6.

46. Ahmed, 2014, 102.

47. June Price Tangney and Ronda L. Dearing, Shame and Guilt (New York: Guilford Press, 2002), 18-24; see also Ahmed, 2014, 105 and Jesse A. Allpress et al., “Atoning for Colonial Injustices: Group-Based Shame and Guilt Motivate Support for Reparation,” International Journal of Conflict and Violence 4, no. 1 (2010): 77. 
Please Cite Final Version; Critical Philosophy of Race 9, no. 2: 342-368.

48. Tangney and Dearing, 2002, 18-25.

49. Helen Block Lewis, Guilt and Shame in Neurosis (New York: International Universities Press, 1971); June Price Tangney et al., "Relation of Shame and Guilt to Constructive Versus Destructive Responses to Anger Across the Lifespan," Journal of Personality and Social Psychology 70, no. 4 (1996): 797-8; Tangney and Dearing, 2002; June Price Tangney, Jeff Stuewig, and Debra J. Mashek, "Moral Emotions and Moral Behavior," Annual Review of Psychology 58 (2007): 347-52; June Price Tangney, Jeff Stuewig, and Andres G. Martinez, "Two Faces of Shame: The Roles of Shame and Guilt in Predicting Recidivism," Psychological Science 25, no. 3 (2014): 799.

50. Tangney and Dearing, 2002, 25.

51. Allpress et al., 2010, 77-8; Ilona E. De Hooge, Marcel Zeelenberg, and Seger M.

Breugelmans, "Restore and Protect Motivations Following Shame," Cognition and Emotion 24, no. 1 (2010): 111-2; Nicolay Gausel and Colin Wayne Leach, “Concern for Self-Image and Social Image in the Management of Moral Failure: Rethinking Shame," European Journal of Social Philosophy 41 (2011): 468-9; Gausel et al., "Defend or Repair: Explaining Responses to In-Group Moral Failure by Disentangling Feelings of Shame, Rejection, and Inferiority,” Journal of Personality and Social Psychology 102, no. 5 (2012): 941-2; Tomasz Czub, "Shame as a SelfConscious Emotion and Its Role in Identity Formation," Polish Psychological Bulletin 44, no. 3 (2013): 248-50; Jonas H. Rees, Jesse A. Allpress, and Rupert Brown, “Nie Wieder: Group-Based Emotions for In-Group Wrongdoing Affect Attitudes to Unrelated Minorities," Political Psychology 34, no. 3 (2013): 389; Jesse A. Allpress et al., "Two Faces of Group-Based Shame: Moral Shame and Image Shame Differentially Predict Positive and Negative Orientations to Ingroup Wrongdoing," Personality and Social Psychology Bulletin 40, no. 10 (2014): 1271-2. 
Please Cite Final Version; Critical Philosophy of Race 9, no. 2: 342-368.

52. Allpress et al., 2014, 1272-3; Rees, Allpress, and Brown, 2013, 387-402. I think it likely that "moral shame" and "image shame" are often experienced in tandem; however, it seems correct that some experiences of shame focus on a person's moral failures, and some on social image. 53. Allpress et al., 2014, 1281.

54. Gausel and Leach, 2011, 468-72; Gausel et al., 2012, 943-4.

55. Gausel et al., 2012, 949 and 953.

56. Ibid., 952-7.

57. Barbara Buch, "Canada/North America: Shame Between Indigenous Nature-Connectedness, Colonialism and Cultural Disconnection," in The Value of Shame: Exploring a Health Resource in Cultural Contexts, ed. Elisabeth Vanderheiden and Claude-Hélène Mayer (Cham, Switzerland: Springer Publishing, 2017), 180-3; De Hooge, Zeelenberg, and Breugelmans, 2010, 122-4; Ilona E. De Hooge, Marcel Zeelenberg, and Seger M. Breugelmans, “A Functionalist Account of Shame-Induced Behavior," Cognition and Emotion 25, no. 5 (2011): 944; Gausel et al., 2012, 943.

58. Allpress et al., 2010, 79-80.

59. Ibid., 81.

60. Jason B. Luoma et al., "Slow and Steady Wins the Race: A Randomized Clinical Trial of Acceptance and Commitment Therapy Targeting Shame in Substance Use Disorder," Journal of Consulting and Clinical Psychology 80, no. 1 (2012): 45.

61. Ibid., 51.

62. Buch, 2017, 180-3; Claude-Hélène Mayer and Louise Tonelli, “'Dream on — There is no Salvation!': Transforming Shame in the South African Workplace Through Personal and Organisational Strategies," in The Value of Shame: Exploring a Health Resource in Cultural 
Please Cite Final Version; Critical Philosophy of Race 9, no. 2: 342-368.

Contexts, ed. Elisabeth Vanderheiden and Claude-Hélène Mayer (Cham, Switzerland: Springer Publishing, 2017), 147-8 and 150-1; Samantha Brennan, Neville Robertson, and Cate Curtis, "Shame and Resilience: A New Zealand Based Exploration of Resilient Responses to Shame," in The Value of Shame: Exploring a Health Resource in Cultural Contexts, ed. Elisabeth Vanderheiden and Claude-Hélène Mayer (Cham, Switzerland: Springer Publishing, 2017), 202 and 215-7.

63. Tangney, Stuewig, and Martinez, 2014, 799.

64. Ibid., 801-2.

65. Ibid., 803.

66. This is particularly true because shame is experienced differently across genders; women may be more likely to feel shame (see Hypatia 33 (3) [2018]). I neglect to discuss gender in this article, however, because the research differs significantly from that concerning white shame. 67. Alexis Shotwell, Knowing Otherwise: Race, Gender, and Implicit Understanding (University Park: The Pennsylvania State University Press, 2011), 87.

68. Medina, 2016, 188 and 193-8; see also 2013b, 22.

69. Megan Boler, Feeling Power: Emotions and Education (New York: Routledge, 1999), 176-9; Esther O. Ohito, “Making the Emperor's New Clothes Visible in Anti-Racist Teacher Education: Enacting a Pedagogy of Discomfort with White Preservice Teachers," Equity \& Excellence in Education 49, no. 4 (2016): 455-8.

70. Williams, 1993, 84-94; Lebron, 2013, 18; Ahmed, 2014, 105-8; Shotwell, 2017.

71. Young, 2011, 108-9.

72. Lisa Guenther, "Resisting Agamben: The Biopolitics of Shame and Humiliation," Philosophy and Social Criticism 38, no. 1 (2012): 61-2. 
73. Shotwell, 2011, 90 and 96.

74. Lorde, 1984/2007, 105-6.

75. Ahmed, 2014, 200.

76. Alcoff offers a compatible view in her account of "white double consciousness," explaining how white people might attend to negative facts about whiteness and also work, with a hopeful mindset, toward a more just future (Linda Martín Alcoff, The Future of Whiteness [Cambridge: Polity Press, 2015], 136-7, 170-5, 187-8, and 204).

77. Berenice Fisher, "Guilt and Shame in the Women's Movement: The Radical Ideal of Action and Its Meaning for Feminist Intellectuals,” Feminist Studies 10, no. 2 (1984): 188.

\section{Reference List}

Ahmed, Sara. 2005. “The Non-Performativity of Anti-racism.” Borderlands 5 (3). http://www.borderlands.net.au/vol5no3_2006/ahmed_nonperform.htm. 2014. The Cultural Politics of Emotion. $2^{\text {nd }}$ ed. Edinburgh: Edinburgh University Press.

Ajayi, Luvvie. 2018. “About the Weary Weaponizing of White Women's Tears.” Awesomely Luvvie (blog). 7 April, 2018. https://www.awesomelyluvvie.com/2018/04/weaponizingwhite-women-tears.html.

Alcoff, Linda Martín. 1998. “What Should White People Do?” Hypatia 13 (3): 6-26. . 2007. "Epistemologies of Ignorance: Three Types." In Race and Epistemologies of Ignorance, edited by Shannon Sullivan and Nancy Tuana, 39-58. Albany: State University of New York Press. . 2015. The Future of Whiteness. Cambridge: Polity Press. 
Please Cite Final Version; Critical Philosophy of Race 9, no. 2: 342-368.

Allpress, Jesse A., Fiona Kate Barlow, Rupert Brown, and Winnifred R. Louis. 2010. “Atoning for Colonial Injustices: Group-Based Shame and Guilt Motivate Support for Reparation.” International Journal of Conflict and Violence 4 (1): 75-88.

, Rupert Brown, Roger Giner-Sorolla, Julien A. Deonna, and Fabrice Teroni. 2014. "Two

Faces of Group-Based Shame: Moral Shame and Image Shame Differentially Predict

Positive and Negative Orientations to Ingroup Wrongdoing.” Personality and Social

Psychology Bulletin 40 (10): 1270-1284.

Baldwin, James. 1962. "A Letter to My Nephew.” The Progressive. 1998 [1965]. “White Man's Guilt.” In Black on White: Black Writers on What it Means to be White, edited by David R. Roediger, 320-325. New York: Schocken Books.

Boler, Megan. 1999. Feeling Power: Emotions and Education. New York: Routledge.

Brennan, Samantha, Neville Robertson, and Cate Curtis. 2017. "Shame and Resilience: A New Zealand Based Exploration of Resilient Responses to Shame.” In The Value of Shame: Exploring a Health Resource in Cultural Contexts, edited by Elisabeth Vanderheiden and Claude-Hélène Mayer, 201-222. Cham, Switzerland: Springer Publishing.

Buch, Barbara. 2017. “Canada/North America: Shame Between Indigenous NatureConnectedness, Colonialism and Cultural Disconnection.” In The Value of Shame: Exploring a Health Resource in Cultural Contexts, edited by Elisabeth Vanderheiden and Claude-Hélène Mayer, 157-186. Cham, Switzerland: Springer Publishing.

Card, Claudia. 2010. Confronting Evils: Terrorism, Torture, Genocide. New York: Cambridge University Press.

Czub, Tomasz. 2013. "Shame as a Self-Conscious Emotion and Its Role in Identity Formation." Polish Psychological Bulletin 44 (3): 245-253. 
Please Cite Final Version; Critical Philosophy of Race 9, no. 2: 342-368.

De Hooge, Ilona E., Marcel Zeelenberg, and Seger M. Breugelmans. 2010. "Restore and Protect Motivations Following Shame.” Cognition and Emotion 24 (1): 111-127.

, Marcel Zeelenberg, and Seger M. Breugelmans. 2011. “A Functionalist Account of Shame-Induced Behavior.” Cognition and Emotion 25 (5): 939-946.

Du Bois, W.E.B. 1998 [1920]. “The Souls of White Folk.” In Black on White: Black Writers on What it Means to be White, edited by David R. Roediger, 184-200. New York: Schocken Books.

Fisher, Berenice. 1984. "Guilt and Shame in the Women's Movement: The Radical Ideal of Action and Its Meaning for Feminist Intellectuals.” Feminist Studies 10 (2):185-212.

Frye, Marilyn. 1992. "White Woman Feminist.” In Willful Virgin: Essays in Feminism, 19761992. Freedom, CA: Crossing Press.

Gausel, Nicolay and Colin Wayne Leach. 2011. "Concern for Self-Image and Social Image in the Management of Moral Failure: Rethinking Shame.” European Journal of Social Philosophy 41: 468-478.

, Colin Wayne Leach, Vivian L. Vignoles, and Rupert Brown. 2012. "Defend or Repair: Explaining Responses to In-Group Moral Failure by Disentangling Feelings of Shame, Rejection, and Inferiority.” Journal of Personality and Social Psychology 102 (5): 941960.

Guenther, Lisa. 2012. "Resisting Agamben: The Biopolitics of Shame and Humiliation." Philosophy and Social Criticism 38 (1): 59-79.

Haggerty, Daniel. 2009. "White Shame: Responsibility and Moral Emotions.” Philosophy Today 53 (3): 304-316.

Hamad, Ruby. 2018. "How white women use strategic tears to silence women of colour." The 
Please Cite Final Version; Critical Philosophy of Race 9, no. 2: 342-368.

Guardian. 7 May 2018. https://www.theguardian.com/commentisfree/2018/may/08/howwhite-women-use-strategic-tears-to-avoid-accountability.

Jones, Janine. 2004. "The Impairment of Empathy in Goodwill Whites for African Americans." In What White Looks Like: African-American Philosophers on the Whiteness Question, edited by George Yancy, 65-86. New York: Routledge.

Kuttner, Robert. 2018. "Stop Wallowing in Your White Guilt and Start Doing Something for Racial Justice." The American Prospect. 21 August, 2018. http://prospect.org/article/stopwallowing-your-white-guilt-and-start-doing-something-racial-justice.

Lebron, Christopher J. 2013. The Color of Our Shame: Race and Justice in Our Time. New York: Oxford University Press.

Lewis, Helen Block. 1971. Guilt and Shame in Neurosis. New York: International Universities Press.

Lorde, Audre. 1984/2007. Sister Outsider: Essays and Speeches. New York: Ten Speed Press.

Luoma, Jason B., Barbara S. Kohlenberg, Steven C. Hayes, and Lindsay Fletcher. 2012. "Slow and Steady Wins the Race: A Randomized Clinical Trial of Acceptance and Commitment Therapy Targeting Shame in Substance Use Disorders.” Journal of Consulting and Clinical Psychology 80 (1): 43-53.

Mayer, Claude-Hélène and Louise Tonelli. 2017. “'Dream on — There is no Salvation!': Transforming Shame in the South African Workplace Through Personal and Organisational Strategies." In The Value of Shame: Exploring a Health Resource in Cultural Contexts, edited by Elisabeth Vanderheiden and Claude-Hélène Mayer, 135156. Cham, Switzerland: Springer Publishing.

Medina, José. 2013a. “Color Blindness, Meta-Ignorance, and the Racial Imagination.” Critical 
Please Cite Final Version; Critical Philosophy of Race 9, no. 2: 342-368.

Philosophy of Race Special Issue: Beyond the Black/White Binary 1 (1): 38-67.

. 2013b. The Epistemology of Resistance: Gender and Racial Oppression, Epistemic

Injustice, and Resistant Imaginations. New York: Oxford University Press.

. 2016. “On Refusing to Believe: Insensitivity and Self-Ignorance.” In Rationality

Reconsidered: Ortega y Gasset and Wittgenstein on Knowledge, Belief, and Practice,

edited by Astrid Wagner and José María Ariso, 187-200. Chicago: De Gruyter.

Mills, Charles W. 1997. The Racial Contract. Ithaca: Cornell University Press.

. 2007. "White Ignorance." In Race and Epistemologies of Ignorance, edited by Shannon

Sullivan and Nancy Tuana, 11-38. Albany: State University of New York Press.

Moraga, Cherríe and Gloria Anzaldúa. 2015. “And When You Leave, Take Your Pictures With

You: Racism in the Women's Movement.” In This Bridge Called My Back: Writings by

Radical Women of Color, edited by Cherríe Moraga and Gloria Anzaldúa, 57-59. $4^{\text {th }}$ ed.

Albany: State University of New York Press.

Morgan, Michael L. 2008. On Shame. New York: Routledge.

Motwani Accapadi, Mamta. 2007. “When White Women Cry: How White Women’s Tears

Oppress People of Color.” College Student Affairs Journal 26 (2): 208-215.

Ohito, Esther O. 2016. “Making the Emperor's New Clothes Visible in Anti-Racist Teacher

Education: Enacting a Pedagogy of Discomfort with White Preservice Teachers.” Equity \& Excellence in Education 49 (4): 454-467.

Oluo, Ijeoma. 2017. “White People: I Don’t Want You To Understand Me Better, I Want You To

Understand Yourselves.” Medium: The Establishment. February 7, 2017.

https://medium.com/the-establishment/white-people-i-dont-want-you-to-understand-me-

better-i-want-you-to-understand-yourselves-a6fbedd42ddf. 
Please Cite Final Version; Critical Philosophy of Race 9, no. 2: 342-368.

Rees, Jonas H., Jesse A. Allpress, and Rupert Brown. 2013. "Nie Wieder: Group-Based Emotions for In-Group Wrongdoing Affect Attitudes to Unrelated Minorities.” Political Psychology 34 (3): 387-407.

Shotwell, Alexis. 2011. Knowing Otherwise: Race, Gender, and Implicit Understanding. University Park: The Pennsylvania State University Press. . 2017. “Is It White Shame?” Alexis Shotwell (blog), August 13, 2017. https://alexisshotwell.com/2017/08/13/white-shame/.

Srivastava, Sarita. 2005. "'You're Calling Me a Racist?' The Moral and Emotional Regulation of Antiracism and Feminism." Signs 31 (1): 29-62. . 2006. "Tears, Fears and Careers: Anti-racism and Emotion in Social Movement Organizations." The Canadian Journal of Sociology 31 (1): 55-90.

Sullivan, Shannon. 2012. "On the Need for a New Ethos of White Antiracism.” philoSOPHIA 2 (1): 21-38. 2014. Good White People: The Problem with Middle-Class White Anti-Racism. Albany, State University of New York Press.

Tangney, June Price, Patricia E. Wagner, Deborah Hill-Barlow, Donna E. Marschall, and Richard Gramzow. 1996. "Relation of Shame and Guilt to Constructive Versus Destructive Responses to Anger Across the Lifespan.” Journal of Personality and Social Psychology 70 (4): 797-809. and Ronda L. Dearing. 2002. Shame and Guilt. New York: Guilford Press. , Jeff Stuewig, and Debra J. Mashek. 2007. “Moral Emotions and Moral Behavior.” Annual Review of Psychology 58: 345-372. , Jeffrey Stuewig, and Andres G. Martinez. 2014. "Two Faces of Shame: The 
Please Cite Final Version; Critical Philosophy of Race 9, no. 2: 342-368.

Roles of Shame and Guilt in Predicting Recidivism." Psychological Science 25 (3): 799805.

Taylor, Paul C. 2004. "Silence and Sympathy: Dewey's Whiteness.” In What White Looks Like: African-American Philosophers on the Whiteness Question, edited by George Yancy, 227-242. New York: Routledge.

__. 2007. "Race Problems, Unknown Publics, Paralysis, and Faith.” In Race and Epistemologies of Ignorance, edited by Shannon Sullivan and Nancy Tuana, 135-151. Albany: State University of New York Press.

Vice, Samantha. 2010. "'How Do I Live in This Strange Place?"” Journal of Social Philosophy 41 (3): 323-342. . 2016. "Essentializing Rhetoric and Work on the Self." Philosophical Papers 45 (1 and 2): 103-131. . 2017. "Race, Luck, and the Moral Emotions." In The Routledge Companion to Philosophy of Race, edited by Paul C. Taylor, Linda Martín Alcoff, and Luvell Anderson, 446-460. New York: Routledge.

Williams, Bernard. 1993. Shame and Necessity. Berkeley: University of California Press. Yancy, George. 2015. "Introduction." In White Self-Criticality Beyond Anti-Racism: How Does It Feel to be a White Problem?, edited by George Yancy, xi-xxvii. New York: Lexington Books. 2018. Backlash: What Happens When We Talk Honestly About Racism in America. Lanham, MD: Roman \& Littlefield. Young, Iris Marion. 2011. Responsibility for Justice. New York: Oxford University Press. 